\title{
EXTEREME AND EXCLUSIONARY LOGIC IN THE AUTHORITARIAN CULTURE AND NATIONAL CHARACTER OF SERBS AS AN OBSTACLE TO QUALITY THINKING, DIALOGUE AND TOLERANCE
}

\begin{abstract}
This paper deals with bivalent logic in Serbian national culture which leads to exclusionary opinions and divisions of opinions into only two basic extreme options. Such logic leads to oversimplification of reality consequently resulting in a series of negative phenomenas: above of all, low quality of dialogue, understanding, tolerance.
\end{abstract}

Key words: exclusionism, extremity in thought, attitudes, Serbs, dialogue, bivalent logic

\section{Introduction}

Due to illiteracy, ignorance, but also authoritarian structure of personality with rigidity as its dominant feature, a certain phenomenon occurs in Serbian people: the recognizable practice of crude thinking in extreme, mutually exclusive categories. There exists no gradation or graduality, no refinement in opinions. It is as if there is only one type of compartmentalisation and division in the mind of the average Serbian man which divides everything into only two extremes in a sharp, rough and almost schizophrenic manner. Therefore, there exists no emphasis on gradation of reasoning and expression of opinion. It is important to note that such extreme and exclusive attitudes occur mainly due to impulsiveness. This means that such unculturedness and non-differentiation of opinion is accompanied by fitting emotions and possesses a strong irrational basis. Serbian psychiatrists, ethnologists and ethno-psychologists (Marić 2009: 11; Jovanović 2008: 136; Jerotić) ascribe choleric temperament to Serbian people. Among Serbs there are many who react in a rash and hasty manner without forethought and delaying the reaction. This is often explained by the so-called "southern temperament" with unculturedness lurking beneath it. (Jovanović 2008: 258). It is possible that such a claim should not be interpreted as stating that Serbs are dominated by individuals with inborn choleric temperament but that such rash and aggressive reactions are the result of a lower level of culturedness. This impulsiveness and volatileness is further intensified by frustrations caused by constant economic and social crisis.

\footnotetext{
${ }^{1}$ Received September 2019 / Accepted November 2019

22E-mail: zikicasimic@yahoo.com
} 


\section{Dichotomous exclusionism in attitudes and emotions}

There are numerous examples which can serve to show abrupt shifts in thought going from one extreme to another and which have the abovementioned tumultuous emotional basis. It is well known in everyday and colloquial conversations that if you criticise an average Serb for singing in a particular situation, that it is inappropriate or not in accordance with his social role, position and reputation, that person will, in order to justify oneself, very often reply in an angry manner using a rhetorical question reflecting an opposite extreme: "Should I cry instead?" This counteracts things in such a radical manner as if there were no transitionary emotional states (moods, feelings) between singing and crying. Furthermore, you will also encounter a similar reaction if, for example, you say that wealth should not be the highest goal of life, because such an aspiration leads to the risk of forgetting the basic altruistic and moral values. In fact, people tend to overlook the fact that not being rich does not automatically mean being poor for there are numerous levels representing moderate financial situations, not simply poverty or luxury as only options. In addition, while the poor are usually characterized as being good, the rich are often attributed negative character traits (selfishness, materialism). "The poor often act in a way the rich would never have imagined (...). The poor are in no advantage in comparison to the rich, nor are the rich in advantage to the poor simply because of their economic status" (Bishop of Niš John 1959: 41-42).

Likewise, when avid believers, uncritically and unconditionally devoted to the Church, or priests themselves, try to defend the Church from justified criticism on the matter of a large number of clergy, especially dignitaries, driving luxury cars which is not in accordance with Christian ideals and monastic vows of modesty and thus "not sharing the (economic) fate of the people", most of them will angrily respond to you: "Ah, should they ride a donkey (or a bicycle) instead!?". Their attitude will exude an opinion that there is no middle option between these two extremes - average, functional and inexpensive cars that would serve that purpose. Anyone who criticizes such luxury will be characterised as a 'hater', or communist. A certain practice has become widespread to disqualify someone's argument - it has become sufficient to state that the one criticising has negative motives for criticism (maliciousness, tendentiousness, envy and hatred) to automatically disqualify that person's arguments. In fact, the matter is far more complex. Each criticism, not only malicious and ungrounded but also well-grounded one, will be crudely characterised as "spitting" on the Church or envy and maliciousness will be identified as the basis for such a critical attitude towards luxurious lifestyle. "The public exudes exclusionary, black-and-white attitudes, provincialism, and a reluctance to think differently, which is condition sine qua non of the refinement of thought. There is widespread hatred in the public today. People are more aware of what they are against than what they are for. People rather vote against someone and something than for".

\footnotetext{
${ }^{3}$ Slaviša Orlović, Dijalog - susret razlika, http://demostat.rs/sr/vesti/dijalog/prof-dr-slavisa-orlovicdijalog---susret-razlika/261, 3.10.2017.
} 
When a certain phenomenon is overcome, becomes obsolete or suppressed, it is replaced by a complete opposite. "There exists an extremely widespread and bad spiritual habit that persists in the way we think: One thought, as soon as it is proven incorrect, we immediately replace it with the opposite, not realising that this new thought may also be wrong, and some third. (fourth, or fifth ...) thought the correct one. Perhaps this thesis-antithesis form of thinking is the source of constant conflict with others (...), the world is far more complex than this simplified duality, and until one realizes this, one will always be prone to simpleton-like and vulgar conflicts and arguments. It is necessary to abandon the formal-logical thinking and resort to a more dialogical and versatile one. This bivalent, dichotomous logic simplifies both thought and life, since thought and life function, by rule, by way of gradation and not logical extremes: either bow down or be excluded! These binary divisions and this simplification of numerous possibilities into only two (black and white), although logical to a certain extent, are very dangerous. Julio Cortázar noted: Between for and against, how much is a maybe? (Šušnjic 2004: 10-12). "Here's an example. Man must subdue himself to nature. Nature must be subjected to man. To live in harmony with nature. Here is another example. God exists. God does not exist. God exists for those who believe in Him and does not exist for those who do not believe in Him." (Šušnjic 1997: 208).

There is only the enemy and the division to myself and the others. This simplification makes the fight easier. For the Communists, there is only one enemy fascism. Any opponent of communism is therefore a fascist. And vice versa. People tend to side with the Communists out of hatred towards fascism. Unification is conducted in opposition to the Devil that represents the other half of the world. Fanatical intolerance places before wrong choices people and imposes absurd divisions (Berdyaev 2002: 428-9). This is in opposition with to democracy which is based on the tolerance and respect for multitude of differences and their coexistence (Jovanović 2012: 160).

Thus, after rejecting the vulgar and ideological Marxism forced upon and imposed on all fields of scientific and public life, Marxism itself, as a philosophical, economic and sociological theory, was often controverted, understated and rejected. It is often the case of "throwing out both dirty water and a child out of the trough". The Communists have rejected both the faith and the Church, due to the reactionary role of the Church in excusing social injustices and unjust social systems. The Church has, likewise, rejected communism in its entirety due to its atheistic and antitheistic aspect.

After we had finally rejected both communism and Yugoslavia, we "returned" to Orthodoxy and Serbianesses as another extreme. "Some idols have been replaced by others: folk heroes by saints, Sava the commander by Saint Sava, dissidents by national and religious enemies" (Bogdanović 2011:34). Simultaneously with this ideological and identity, transformation came in the economic sphere, in the forms of property. There was a sudden shift from social and state ownership to radical neoliberal privatization (from the media to agricultural cooperatives) in accordance with the ideas of the 
political leaders in Serbia, in the period following the October 2000, and in the spirit of the economic maxim of Jeffrey Sachs that everything should be privatized as soon as possible. "The change of ownership, despite the constitutionally guaranteed equality of the various forms of property (private, collective and state), is reflected in reality as a goal of its own and less as an instrument for achieving better economic results" (Vuković 2014: 93). Isaac Adigez, one of the world's greatest economists, notes: You have misapplied capitalism. You have escaped the socialist self-governing system by 180 degrees. (...). It's a mistake. You do not go from here to the other side. No! There's no middle option. You're copying the West in a vulgar manner now. ${ }^{4}$

Strict antagonism in expression is equally represented in the political life of Serbia, in the field of thinking, feeling, and behaviour. For example, if you are an opponent of the widely hated government, there must be no exception. You have to counter everything and be absolutely against the authorities. Otherwise, you will be characterised as a sympathiser of this widely hated government. You might as well be a bitter opponent of the current government, it will not be obstacle for others to characterise you as a "bot" - supporter, member and paid agitator of the government on social networks or in real life. Our famous writer S. Basara sees such psychology as uncultivated and barbaric ${ }^{5}$.

In the spirit of exclusiveness, Serbs maintain an absolute identification of national and religious affiliation, that is, a denominational mentality. As an example, a German is German be he a Catholic or a Protestant, Roma is a Roma whether he is an Orthodox Christian, a Catholic, a Muslim, and more recently, a Protestant, and an American is an American regardless of religious, racial and ethnic origin and background, an Albanian is an Albanian even if he is a Muslim, a Catholic or an Orthodox Christian (in Albania). However, a Serb is only a Serb if he is Orthodox, and in no way if he is a Catholic or a Muslim (and more recently a Protestant). "No long ago, there were a lot of Serbs of Catholic and Muslim faith, so Vuk Karadžić could write laconically about the Serbs of three laws - of Orthodox, Catholic and Muslim law. This is extremely rare nowadays, even insignificant, (...) partly due to the attitude of the Serbian Orthodox Church (SOC) which recognises only the Orthodox Christians as Serbs" (Đorđević 2016: 106). The Serbian elite have also reduced the number of Serbs, declaring Islamic and Catholic compatriots to be "Turks" and "Šokci", and turning them into sworn enemies. The SOC is incapable of separating nationality and denomination and distinguishing the difference between the earthly and the heavenly (Basara 2018: 75). What is very indicative and contradictory is that, simultaneously with rejection, non-recognition and non-acceptance of Serbs of other denominations as part of Serbian nation, their right to national identity is being denied - it is claimed that they do not have their own language but use the Serbian language.

An overdeveloped tribal identity, as a type of extremism, possesses in itself a sense of group identity that overpowers all other affiliations. In psychology, according

\footnotetext{
${ }^{4}$ Adiges Isaak, https://www.youtube.com/watch?v=zJDbo3XnZI8, Profil i profit, 31. 03. 2019.

${ }^{5}$ Basara Svetislav, Psihologija ujedinjenja ili smrt, Danas, 18. 09. 2019.
} 
to some authors such as Amin Maluf, this identity is also called a monolithic, simple, exclusionary identity. It is frequently reduced to ethnic, racial or religious affiliation, which is glorified and towards which absolute loyalty is formed. One can only be a Christian or a Muslim, and belong to only one nation. Mixed identity is not acknowledged, only 'pure' one is, considering the fact it is unchangeable by birth. This tribal identity is the source of intolerance, xenophobia and conflict. Any concept which reduces people to a single affiliation inadvertently leads to intolerant behaviour. Their vision of the world is distorted. It is black and white, exclusionary, Manichean, and in it there exist only two sides - good and evil, angels and devils (Maluf, 2003). The current issue concerning Nikola Tesla's national identity and claiming of an exclusive right to him is an illustrative example of non-recognition of a "mixed" identity and insistence on a pure, one-dimensional identity. Namely, Serbian and Croatian nationalists claim the exclusive right and hold this scholar of world fame and importance as their own. These arguments over whom Tesla actually belongs to have become official in the form of a quarrel between the competent representatives of the Serbian and Croatian authorities. In reality, Tesla was a Croatian citizen (born and lived in Croatia), an ethnic orthodox Serb (whose father was an orthodox priest), and most importantly, an American scientist for it was the United Stated provided him with the means and conditions to become the world's most valuable scientist. Members of these two passionately nationalistic and conflicted groups would want to deny him his other identities, and only attribute to him their own identity, despite him being a person with complex, multi-layered and partial affiliation to different identities. Likewise, Nobel laureate Ivo Andrić, although an ethnic member of the Croatian people and of the Catholic faith, is considered one of the Serbian writers because of the style in which he wrote. So was the case with Meša Selimović. Although a Muslim, he is considered a Serbian writer. At least the Serbian side believes in it.

Serbian nationalists whose love for their nation and country (patriotism) does not evolve into arrogant transgression and contempt, underestimation and even hatred of other nations are rare. What is considered a healthy and acceptable nationalism or patriotism almost evolves into chauvinism, especially towards those who are not considered national "friends". "The superiority of the ethnic We, with whom individuals identify, necessarily produces the inferiority of the Other" (Božilović 2014: 52). Similarly, we have either "the first Serbian" xenophobia towards the West, which is more advanced and superior in civilization terms (in material, technical, scientific, institutional and political terms), or we have "the second Serbian" uncritical worship, glorification and adoption of all that comes from the West. Serbia has always been torn between either uncritically identifying with the West (merely imitating its values) or rejecting it absolutely. For this reason, all modernization projects in this region carried a strong dualism of the traditional and the modern (Stojanović, 2000: 148). Those in the middle, with a balanced relationship towards these two extremes, are quite rare. Likewise, any nationally self-critical attitude, even when well-grounded, justified and moderate, is disqualified as "auto-chauvinism", and not only when it is truly one-sided, exaggerated, subjective and overly critical to its 
own people and nation. "Unlike nationalists who use fierce criticism of others' crimes to justify their own, Serbian national nihilists overemphasise the responsibility and guilt of their own people for the suffering caused to other nations." (Jovanović ,2009: 133).

Famous Serbian writer Ivo Andric claimed: "Such is our man. He does not think, neither much nor persistently. But as soon as he manages to form a single thought in his head, his first concern is not to elaborate, verify, and compare that thought critically with what other people think of the same thing, but to declare his thought as the only true and right one, and then immediately dig a deep trench of contempt, hatred and strife between that thought and every other thought until the extermination of others." (Andrić, 1981: 205).

According to his mental disposition, the Yugoslav man is a political extremist. Nothing that is moderate, compromising or rational can agitate his political temperament or incite deeper interest (Dvorniković, 2000: 902) .

Serbs have always had trouble communicating with those who think differently. The rivalries, conflicts, and turbulent emotions which can be seen in the Serbian parliament during sessions are a good indicator of intolerance. In these situations "serbian collectivism" is directed towards other Serbs who become "traitors", "foreign mercenaries" and "spies", in one word - "enemies". Supporters of different political parties are insulted and persecuted with tribal hatred, with the inevitable Manichaeistic division into "us" and "them" (Stevanović, 2008: 246).

In fact, such undifferentiation or harshness of opinions (including emotions) on different issues in different areas of life, lack of refinement of attitudes, can also be a consequence of unenlightement and primitivism. Therefore, it is a question of a lack of cultivated thinking, ie. complex, multilayered and precise thinking, which is refined during long-term and high quality education, as well as continuous, deep and sophisticated deliberation.

\section{Authoritarian culture as the basis of exclusivity and intolerance}

Extreme self-assessments, as noted by academician Jerotić, are also given about Serbian nation - we are either the best or the worst (people) ${ }^{7}$, we are either guilty

\footnotetext{
${ }^{6}$ Ethnologist Bojan Jovanović believes that Dvorniković built the character of the Yugoslav nations on the concept of "extended Serbianness", that is, of Serbian national character, by reinforcing the common attributes of Yugoslavian nations and neglecting the character differences between the Yugoslavs nation (2004: 49).

${ }^{7}$ Serbs are regarded as a people who oscillate between extremes in terms of making unrealistic assessments, perceptions of certain situations, from the most positive to the most negative, as well as contradictory self-assessments of their national character. Likewise, they are held as a people inclined to extreme moods. "Our man is inclined to see every phenomenon distorted: either unnaturally magnified or unnaturally diminished, only not as it is (...)" (Šušnjić 2004: 11).

Serbs are characterized by the denial of the "principle of reality", a tendency toward the unrealizable and the utopian. Accordingly, he cites K.K. Rhodophinkin, a Russian diplomat who spoke of the people of Karadjord's Serbia: "Serbs are imaginative in nature ... Serbs never see things as they are, but always
} 
of everything or guilty of nothing. According to him, this is because Serbs think in exclusive categories of "or-or",and not "and-and." Therefore, he argues that logic, discursive thinking is not a stronger side for Serbs, and proposes the implementation of logics as a subject in the curriculum at all faculties in our education system in order to change this situation, for at least one year. "We are very temperamental, sensitive, and irrational, in a negative sense. Beside heart, God has also given reason to man." Therefore, according to Jerotić, Serbs are very prone to dogmatic thinking (rigid attitudes, fanatical reactions, intolerance). "It is as simple as that. Two and two are four. If it's not black - it's white. If it's not white - it's black. And God gave us the rainbow, a spectrum of colours." ${ }^{10}$ In a similar manner, Serbian writer S. Selenić ("Očevi i oci") uses the character of Elizabeth to illustrate how Serbs think in superlatives. On the one hand, the Serbs consider themselves to be a genius people and do not need proof, for they are convinced of it. On the other hand, they are very convinced that Serbia is worth nothing. There is no middle option, no reason." (Petrović 2012: 297). Sociologist Č. Ćupic points out that extremism is shown when we claim to be either the best or the worst nation, but that life goes on in nuances ${ }^{11}$. Thus, a false alternative choice is given between two highly polarizing and conflicting options. One does not realise that things in life are usually not black or white, but most often grey. "We usually think in absolute categories and paint the world in black and white, drawing a sharp line between good and bad, allowed and forbidden, friends and foes ... Disagreement is usually understood as an expression of antagonism, and even deepest friendships hardly survive political disagreement." ${ }^{2}$.

Within an authoritarian political culture there exists an uncritical (black and white) political consciousness. This consciousness easily judges good and evil without clear criteria, in an irrational, spontaneous way. Therefore, certain political figures are idealized and worshiped, while others are satanised and rejected (Butigan 2000:30).

The cause of these phenomena should also be sought in the fact that the authoritarian personality type dominates Serbian mentality. Authoritarian personalities, prone to rigid attitudes and stereotypes, never allow for doubts, feelings, even less understanding for nuances, for any of those views found in the

better or worse than they are. During the war, mood played an enormous role"(Jerotić 2003: 150, 127). This oscillation in collective self-perception was also noticed by Vladimir Dvorniković, arguing that instead of the "first people in the world", the voices of pessimism and negativism could often be heard at "crucial moments"; then the resignation begins: "We are the last nation in the world." " We are worthless! Are there worse peoples than us ?! (Dvorniković 2000: 17).

${ }^{8}$ Jerotic Vladeta, Nepoznato u ljudskom životu, https://www.youtube.com/watch?v=LXgm5qgtQ8o, 3. 09. 2017.

${ }^{9}$ Jerotić Vladeta, Moć verovanja ,https://www.youtube.com/watch?v=R-9SxVfy4bY\&list=RDR-9SxVfy4bY\#t=1964, 25. 05. 2016.

${ }^{10}$ Jerotić Vladeta Pozitivno iI negativno u srpskom pravoslavnom konzervativizmu, 2 https://www. youtube.com/watch?v=1a19uE1hQao, 15.06. 2014

${ }^{11}$ Čupić Čedomir https://www.youtube.com/watch?v=Cr7YKakD-Pg, 11. 09. 2019.

${ }^{12}$ Zoran, http://www.novipolis.rs/dosije/28148/rat-protiv-mentaliteta-drugi-deo.html, 06.05.2016. 
wide area between black and white. This is why an authoritarian personality tends to falsify reality, which implies a variety of forms and multitude of transitions between two or more extremes (Kecmanović 2006: 74). Polarized thinking is characteristic of personalities with an emphasised authoritarian structure. The results of all researches indicate a high degree of authoritarianism in our nation. An empirical study of authoritarianism (Rot, Havelka 1973: 145-153), conducted on high schoolars, confirms this result because it reveals an extremely high level of authoritarianism (the highest score in the world on the Adorno Authoritarian Scale, higher than even US prisoners!). This result is disquieting regardless of the possibility of explaining it partially by methodological (F-scale was not standardized in our country) and cultural reasons (patriarchal consciousness, different cultural norms). Sociological studies of authoritarianism conducted in late 1989 revealed not a decrease in authoritarian consciousness, but an increase in it. Among many, this consciousness no longer had a communist but an anti-communist form (Bogdanović 2011: 34). If everything in our region is happening in extremes, then thinking in the extremes is quite common phenomenon. In Serbia, there is only for and against, and not many people care about what is in between. If most of our people are authoritarian (and all research shows this), then it is logical for them to not be capable of conducting a polite, open and honest conversation: the other person is not perceived as an interlocutor, but as an enemy" (Šušnjic 2004: 12).

A personality prone to extreme, undemocratic and simplified solutions is, as a rule, characterised by Manichean view of the world, that is, by thinking in extreme, rude, black and white categories (good-evil, smart-stupid, friend-enemy). Such a person is incapable of thinking in nuances, finesses, and cannot compromise in politics and interpersonal relationships - you are either a "patriot" or a "traitor", "normal" or "abnormal". There are no intermediate options between these sharply divided and opposing categories, no subtle differences. "Whoever is not with us is against us," he is "the enemy" (Trebješanin 2007: 72). Authoritarian thinking is simplistic (black and white thinking, thinking in rough categories) and I believe it stems largely from the archaic world view. Dogmatism is a phenomenon close to authoritarianism (Bogdanović 1998: 337). Dogmatism, black and white thinking is an uncritical, rigid opinion that does not allow objections and forbids doubt, criticism and scrutiny. It is a personality trait that manifests through intolerance towards different views, in blindly believing the opinions of authority, and in accepting stereotypes and prejudices. This opinion, unlike rational cognition, does not rest on reason and logical facts, but on unconditional belief in dogma, and is contrary to exploratory and critical thinking. Dogmatic thinking is characteristic of an authoritarian personality, who believes that the only correct opinion is that of the group to which he or she belongs. Extremists have a simplistic view of the world, are prone to dogmatic thinking and have a "narrow mind". Knowledge and attitudes of dogmatic people are influenced by external authority, not logical arguments and critical search for truth (Vuković, Milosavljević 2015: 127). 


\section{Conclusion}

Black and white thinking narrows our views of the world. When we think in dichotomous categories we fail to grasp numerous alternative ways of viewing the world. We are less capable of flexibility, adaptation and compromise.

This form of thinking begins with the assumption that we aware of the line dividing what is good and what is not good. The truth is that we do not know and remain trapped within the confines our own categories of thinking, which often prove to be delusions or prejudices, and as such are the source of intolerance towards others. "Discourse and tolerance are a prerequisite for revealing the truth. Tolerant person admits to not knowing the truth, the whole truth. Intolerant person is one who thinks he knows the truth, the whole truth. The fate of the former is to learn and develop; the fate of the latter is to stagnate or to degrade. One who incapable of hearing the other is prone to self-deception without realising it (Šušnjic, 1997: 208).

\section{References}

Andrić, I. (1983, Знакови ӣоред ӣyйа. Београд: Рад

Basara, S. (2018). Atlas pseudomitologije. Beograd: Službeni glasnik.

Berđajev, N. (2002). Човек и машина. Београд: Бримо.

Bogdanović, M. (2011). Prokletstvo nacije. Novi Sad: Eden.

Butigan, V. (2000). Politička kultura na Balkanu. Niš: Filozofski fakultet

Bojanović, R (1998). „Osobine ličnosti i prihvatanje teorija zavere”.

Psihologija, 31 (4). Časopis društva psihologa Srbije: Beograd. (pp 327-342).

Dvorniković, V. (2000). Karakterologija Jugoslovena, Beograd: Prosveta.

Vuković, M. (2014). Neophodnost revitalizacije sela u Srbiji. Ed. N. Bogdanović. Selo neveselo. Novi Sad: Prometej, Niš: Hamimontana, Niš: Mašinski fakultet. (pp 91-999).

Vuković, N., Milosavljević, Z. (2015). „Politički oblici ekstremizma“. Vojno delo. Vojnoizdavački zavod : Beograd.

Episkop niški, J. (1959). Beseda na gori (stara istina u novom vremenu). Niš.

Đorđević, B. D. (2016), „Moj komšija pravoslavac“. Ed. D.B. Đorđević. Džepna sociologija za početnike. Novi Sad: Prometej, Niš: Mašinski fakultet.

Jerotić, V. (2003). Srbi i Srbija. Beograd: Ars libri, Banjaluka: Besjeda.

Jovanović, B. (2004). Karakter kao sudbina. Beograd: Narodna knjiga, Beograd: Alfa.

Jovanović, B. (2008). Prkos i inat (etnopsihološke studije). Beograd: Zavod za udžbenike.

Jovanović, B. (2009). Rečnik javašluka. Novi Sad: Prometej.

Jovanović, Đ. (2012). Prilagođavanje (Srbija i moderna od strepnje do sumnje). Niš: SVEN, Beograd: Institut za sociološka istraživanja Filozofskog fakulteta.

Kecmanović, D. (2006). Da li smo sišli s uma ili dokaži da si Srbin (o etnonacionalizmu i nama). Sremski Karlovci: Izdavaštvo knjižarnice Zorana Stojanovića. 
Maluf, A. (2003). Ubilački identiteti. Beograd: Paidea.

Marić, J. (2009). Kakvi smo mi Srbi, (Upamet se Srbi: Mali priručnik za korekciju sopstvenih nesavršenosti). Novi Sad: Budućnost.

Petrović, K. (2012). Fenomen „drugosti“ i nacionalnih stereotipa u Selenićevom romanu Očevi i oci. Ed. Popović Srdanović, D. Drugi o Srbima - Srbi o drugima. Niš: Filozofski fakultet

Rot, N., Havelka, N. (1973). Nacionalna vezanost i vrednosti kod srednjoškolske omladine. Beograd: Institut za psihologiju i Institut društvenih nauka.

Stevanović, B. (2008). Politička kultura i kulturni identiteti u Srbiji na Balkanu. Filozofski fakultet: Niš

Stojanović, D. (2000). Nekoliko osobina procesa modernizacije u Srbiji početkom 20. Veka. Ed. Hans-Georg, F., Graorac I. Dijalog povjesničara, istoričara 2. Zagreb: Friedrich Naumann Stiftung.

Trebješanin, Ž. (2007). „Psihologija političkog ekstremizma“. Heretikus - časopis za preispitivanje prošlosti. Beograd: Centar za unapređenje pravnih studija. (pp 67-75).

Šušnjić, Đ.(1997). Dijalog i tolerancija. Beograd: Čigoja štampa.

Šušnjić, Đ. (2004). Granice tolerancij. Novi Sad: Religija i tolerancija.

\section{Website}

Adiges, I. (31 mart 2019). Available on: https://www.youtube.com/watch?v=zJDbo3XnZI8. „Put budućnosti“. Profil i profit. (Accessed decembar 1, 2019).

Basara, S. (18 septembar 2019). „Psihologija ujedinjenja ili smrt“. Danas.

Jerotic, V. (3 septembar 2017). "Nepoznato u ljudskom životu”. Available on: https://www. youtube.com/watch?v=LXgm5qgtQ8o. (Accessed decembar 1, 2019).

Jerotic, V. (25 maj 2016). "Moć verovanja“. Available on: https://www.youtube.com/ watch?v=R-9SxVfy4bY\&list=RDR-9SxVfy4bY\#t=1964. (Accessed decembar 1, 2019).

Jerotic, V. (15 jun 2016). "Pozitivno i negativno u srpskom pravoslavnom konzervativizmu). Available on: https://www.youtube.com/watch?v=1a19uE1hQao. (Accessed decembar 1, 2019).

Orlović, S. (3 novembar 2017). „Dijalog - susret razlika”. Demostat.. Available on: http:// demostat.rs/sr/vesti/dijalog/prof-dr-slavisa-orlovic-dijalog---susret-razlika/261. (Accessed decembar 1, 2019).

Čupić Č. (11 septembar 2019). "Skupštinu treba upristojiti, obračun poslanika s građanima - kukavički“. Novi dan. N1. https://www.youtube.com/watch?v=Cr7YKakD-Pg, 11. 09. (Accessed decembar 1, 2019).

Ćirjaković, Z. (6 maj 2016). Rat protiv mentaliteta.. http://www.novipolis.rs/dosije/28148/ rat-protiv-mentaliteta-drugi-deo.html, 06.05.2016 


\section{EKSTREMNA LOGIKA ISKLJUČIVOSTI U AUTORITARNOJ KULTURI I NACIONALNOM KARAKTERU SRBA KAO SMETNJA KVALITETNOM MIŠLJENJU, DIJALOGU I TOLERANCIJI}

Rezime. Ovaj rad se bavi dvovalentnom logikom u srpskoj autoritarnoj kulturi koja dovodi do veoma isključivih mišljenja i njihove podele na samo dve osnovne krajnosti. Takva logika dovodi do grubog uprošćavanja stvarnosti, a što ima za posledicu čitav niz negativnih pojava: pre svega, nizak kvalitet dijaloga, razumevanja i tolerancije.

Ključne reči: isključivost, ekstremnost u mišljenju, stavovi, Srbi, dijalog, dvovalentna logika 